\title{
Identification of Tyrosyl Residue Present in the High-affinity Saccharide-binding Site of Ricin $\mathrm{D}^{\dagger}$
}

\author{
Takashi Mise, ${ }^{*}$ Tadahisa ShimodA** and Gunki FunAtsu*** \\ Laboratory of Biochemistry, Faculty of Agriculture, \\ Kyushu University, Fukuoka 812, Japan
}

Received July 8, 1985

\begin{abstract}
We analyzed $\left[{ }^{125} \mathrm{I}\right]$ iodotyrosyl residues in the B-chain of ricin $\mathrm{D}$ iodinated at $\mathrm{pH} 7.0$ and $0^{\circ} \mathrm{C}$ for $60 \mathrm{~min}$ in the presence and absence of lactose. Peptides containing such $\left[{ }^{125} \mathrm{I}\right]$ iodotyrosyl residues were isolated from the subtilisin digest of iodinated B-chains by gel filtration on Sephadex G-25 followed by paper chromatography and paper electrophoresis. Their locations in the primary structure were assigned based on their amino acid composition.

In the absence of lactose, five tyrosyl residues were susceptible to iodonation, but their reactivities varied; Tyr- 248 seemed to be the most reactive, followed by Tyr-148, Tyr-78 (or Tyr125), and Tyr-67; Tyr-176 was the least reactive. In the presence of lactose, however, Tyr-248 was completely protected from iodination, and the reactivity of Tyr-67 increased more than two-fold; that of Tyr-78 (or Tyr-125) decreased by about half.

From these and earlier results, we concluded that Tyr-248 exists in the high-affinity saccharidebinding site of the B-chain. Tyr-67 and Tyr-78 (or Tyr-125) may exist next to each other near the low-affinity saccharide-binding site of the B-chain, and their iodination may cause a loss of lactosebinding ability.
\end{abstract}

Ricin, a toxic lectin present in castor bean (Ricinus communis) seeds, consists of an Achain, which inactivates the eukaryotic ribosomes enzymatically, and a B-chain, which agglutinates the cells. ${ }^{1)}$ the B-chain has two distinct saccharide-binding sites, ${ }^{2)}$ and binds divalently to galactose- or $N$-acetylgalactosamine-containing receptors on the cell surface. ${ }^{3)}$ The toxic action of ricin is elicited by a cooperative action of two chains: (a) binding of ricin to the cellular receptors through the B-chain; (b) internalization of ricin into the cells; (c) release of the A-chain from ricin; (d) inactivation of the ribosomes by the A-chain.4)

In previous papers, ${ }^{2,5)}$ we demonstrated that the iodination of ricin $\mathrm{D}$ at $\mathrm{pH} 7.0$ and $0^{\circ} \mathrm{C}$ for 60 min greatly decreases both its cytoagglutinating activity and its toxicity due to the loss of saccharide-binding ability in the low-affinity saccharide-(LA-)binding site. Furthermore, the high-affinity saccharide-(HA-)binding site contains one tyrosyl residue, which can be protected from the iodination by lactose.

Here, we isolated various peptides containing $\left[{ }^{125} \mathrm{I}\right]$ iodotyrosyl residues from the subtilisin digests of the B-chains of ricin D iodinated in the presence and absence of lactose. Based on their amino acid composition, we identified the tyrosyl residue present in the HA-binding site. Also, the loss of saccharidebinding ability in the LA-binding site by iodi-

$\dagger$ This work was supported in part by a Grant-in-Aid for Scientific Research from the Ministry of Education, Science and Culture of Japan.

* Present address: Kirin Brewery Co., Ltd., Tokyo 150, Japan.

** Present address: The Second Institute, Fuji Oil Company, Izumisano 598, Japan.

*** To whom correspondence should be addressed.

Abbreviations: I-ricin D, ricin D iodinated in the absence of lactose; I-ricin D (lac), ricin D iodinated in the presence of lactose; HA-binding site, high-affinity saccharide-binding site; LA-binding site, low-affinity saccharide-binding site. 
nation was investigated.

\section{MATERIALS AND METHODS}

Ricin D was isolated from castor bean seeds produced in Thailand by the method described elsewhere. ${ }^{6)} \mathrm{Na}\left[{ }^{125} \mathrm{I}\right]$ was the product of New England Nuclear Co. and subtilisin BPN' was purchased from Nagase Sangyo Co. All other reagents were of analytical grade.

Iodination of ricin $D$. The iodination of ricin $\mathrm{D}$ was done by the method of Ishiguro et al. ${ }^{7)}$ Ricin D (150 mg) was

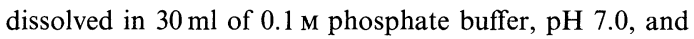
iodination was started by adding $1.88 \mathrm{ml}$ of $0.05 \mathrm{~N} \mathrm{KI}_{3}$ solution containing $200 \mu \mathrm{Ci}$ of $\mathrm{Na}\left[{ }^{125} \mathrm{I}\right]$. Iodination in the presence of lactose was done using $100 \mathrm{mg}$ of ricin D


containing $0.1 \mathrm{M}$ lactose. To this solution, $1.25 \mathrm{ml}$ of $0.05 \mathrm{~N}$ $\mathrm{KI}_{3}$ solution containing $125 \mu \mathrm{Ci}$ of $\mathrm{Na}\left[{ }^{125} \mathrm{I}\right]$ was added. In both cases, the $\mathrm{KI}_{3}$ solution was added gradually over $10 \mathrm{~min}$. The reaction was continued at $0^{\circ} \mathrm{C}$ for $60 \mathrm{~min}$ and then stopped by the addition of one drop of $0.1 \mathrm{M} \mathrm{Na}_{2} \mathrm{~S}_{2} \mathrm{O}_{3}$ solution to the reaction mixture. Iodinated ricin $\mathrm{D}$ was dialyzed against $0.05 \mathrm{~N}, 0.005 \mathrm{~N}$, and finally $0.001 \mathrm{~N}$ acetic acid solution until no radioactivity was found in the outer solution. Ricin D iodinated in the presence and absence of lactose are referred to as I-ricin $\mathrm{D}$ (lac) and I-ricin D, respectively. The number of iodotyrosyl residues was estimated by examining the difference spectrum between iodinated protein solutions at $\mathrm{pH} 10.0$ and at $\mathrm{pH}$ 3.5. We assumed that the molar extinction coefficient of iodotyrosyl residues at $312 \mathrm{~nm}$ and at $\mathrm{pH} 10.0$ was $5815,{ }^{8)}$ and that those of ricin $\mathrm{D}$ and the $\mathrm{A}$ - and B-chains at $280 \mathrm{~nm}$ were $9.15 \times 10^{4}, 3.1 \times 10^{4}$, and $5.94 \times 10^{4}$, respectively.

Isolation of iodinated $A$ - and B-chains. The A- and Bchains of the iodinated ricin $\mathrm{D}$ were separated by a method described elsewhere. ${ }^{9)}$ I-ricin D or I-ricin D(lac) was dialyzed against $5 \mathrm{~mm}$ phosphate buffer, $\mathrm{pH} 8.0$, containing $0.2 \mathrm{M} \mathrm{NaCl}$. To the solution was added 2-mercaptoethanol to the final concentration of $1 \%$, and the $\mathrm{pH}$ was adjusted to 8.0 using $0.2 \mathrm{~N} \mathrm{NaOH}$. The containers were flushed with nitrogen and the reaction was done at room temperature for $60 \mathrm{~min}$. The reduced ricin $\mathrm{D}$ was put on a Sepharose $4 \mathrm{~B}$ column $(3 \times 34 \mathrm{~cm})$ equilibrated with $5 \mathrm{~mm}$ phosphate buffer, $\mathrm{pH} 8.0$, containing $0.1 \% 2$-mercaptoethanol and $0.2 \mathrm{M} \mathrm{NaCl}$, and developed with the same buffer at a flow rate of $63 \mathrm{ml} / \mathrm{hr}$. After elution of the iodinated A-chain, the iodinated B-chain absorbed on the column was eluted with the above buffer containing $0.1 \mathrm{M}$ lactose. These fractions were used without further purification.

Subtilisin digestion. Lyophilized B-chain were suspended in $0.1 \mathrm{M} \mathrm{NH}_{4} \mathrm{HCO}_{3}$ solution and the digestion was started by adding $2 \%$ by weight of subtilisin BPN'. After incubation at $37^{\circ} \mathrm{C}$ for $7 \mathrm{hr}$, an additional $2 \%$ of the enzyme was added to the reaction mixture and the digestion was continued for a further $15 \mathrm{hr}$. The digest was lyophilized.

Gel filtration. The lyophilized digest was dissolved in water and put on a Sephadex G-25 column $(1.9 \times 190 \mathrm{~cm})$ equilibrated with $0.5 \% \mathrm{NH}_{4} \mathrm{HCO}_{3}$ solution. The column was developed with the same solution at a flow rate of $23.7 \mathrm{ml} / \mathrm{hr}$. Then $2-\mathrm{ml}$ fractions were collected and the peptide peaks were detected by measuring the absorbance at $230 \mathrm{~nm}$ and the radioactivity of $20-\mu 1$ portions taken from every other tube.

Paper chromatography and paper electrophoresis. Paper chromatography was done by the descending technique for $13 \mathrm{hr}$ on Whatman $3 \mathrm{MM}$ paper in a solvent of 1butanol-acetic acid-water-pyridine $(15: 3: 12: 10)$. Paper electrophoresis was done on Whatman 1 paper at $135 \mathrm{~V} / \mathrm{cm}$ for $2 \mathrm{hr}$ in a solvent of formic acid-acetic acid-water-acetone $(3: 12: 70: 15)$, pH 1.8 . For the preparative runs, $0.4-\mathrm{cm}$ strips were stained and counted to locate the radioactive peptides. Peptides were eluted from the paper using a $30 \%$ acetic acid or $0.1 \mathrm{~N} \mathrm{NH}_{4} \mathrm{OH}$ solution and evaporated to dryness.

Amino acid analysis. Peptide samples $(5 \sim 20 \mathrm{nmol})$ were hydrolyzed with $0.5 \mathrm{ml}$ of $6 \mathrm{~N} \mathrm{HCl}$ at $110^{\circ} \mathrm{C}$ for $24 \mathrm{hr}$ in evacuated sealed tubes. The hydrolysates were dried and analyzed using a JEOL Automatic Amino Acid Analyzer, Model JLC-6AH.

Assignment of peptides. Location of peptides in the primary structure were assigned based on their amino acid composition. The position of amino acid residues in the Bchain was numbered accordinge to the corrected sequence $^{10)}$ of the sequence reported earlier. ${ }^{11)}$

\section{RESULTS}

\section{Numbers of iodotyrosyl residues in the $A$ - and $B$-chains of iodinated ricin $D$}

The numbers of iodotyrosyl residues in ricin D iodinated at $\mathrm{pH} 7.0$ and $0^{\circ} \mathrm{C}$ for $60 \mathrm{~min}$ in the presence and absence of lactose and in their polypeptide chains are shown in Table I. In the B-chain of I-ricin D(lac), there was nearly one fewer than with I-ricin D; the A-chain of Iricin $\mathrm{D}(\mathrm{lac})$ had slightly more iodotyrosyl residues than I-ricin D did. This result means that lactose protected the B-chain but not the A-chain of ricin D from iodination, which is consistent with earlier results. ${ }^{5}$ Since this work was to identify the tyrosyl residue protected 
TABle I. Number of IOdOTYRosyl Residues IN Ricin D Iodinated in the Presence and ABSENCE OF LACTOSE AND IN Its Polypeptide Chains

Numbers of residues was estimated by measuring the difference spectrum between the iodinated protein so-

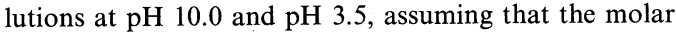
extinction coefficient of iodotyrosyl residue at $312 \mathrm{~nm}$ and at $\mathrm{pH} 10.0$ is 5815 , and that those of ricin $\mathrm{D}$, the Aand B-chains at $280 \mathrm{~nm}$ are $9.15 \times 10^{4}, 3.1 \times 10^{4}$, and 5.94 $\times 10^{4}$, respectively.

Number of iodotyrosyl residues

\begin{tabular}{ccc}
\hline $\begin{array}{c}\text { Iodinated } \\
\text { without } \\
\text { lactose } \\
\text { (A) }\end{array}$ & $\begin{array}{c}\text { Iodinated } \\
\text { with } \\
\text { lactose } \\
\text { (B) }\end{array}$ & (A) $-(\mathrm{B})$ \\
5.23 & 4.79 & -0.44 \\
2.34 & 2.51 & +0.17 \\
3.37 & 2.53 & -0.84 \\
\hline
\end{tabular}

from the iodination by lactose, the B-chain fraction eluted from the Sepharose 4B column by the buffer containing lactose was used for isolation of peptides containing $\left[{ }^{125} \mathrm{I}\right]$ iodotyrosyl residue without further purification.

\section{Isolation of peptides containing $\left[{ }^{125}\right.$ I] iodotyrosyl residue}

The B-chain from I-ricin D and I-ricin $\mathrm{D}$ (lac) was digested at $37^{\circ} \mathrm{C}$ using subtilisin $\mathrm{BPN}^{\prime}$. The suspension of the B-chains became clear after a few hours of digestion. After digestion for $22 \mathrm{hr}$ with stirring, the digests were studied by gel filtration on a Sephadex G25 column. Digests of the two kinds of B-chains gave similar elution profiles with five major radioactive fractions $(\mathrm{I} \sim \mathrm{V}$; Fig. 1). Fraction $\mathrm{I}$ was undigested materials and fraction $\mathrm{V}$ was free iodotyrosine, so they were not analyzed further. The other three fractions were studied by paper chromatography. Figure 2 shows the distribution of radioactivity on the chromatograms and a comparison of the B-chains from I-ricin D and I-ricin D(lac). Only fraction IV had a similar chromatographic patterns for both kinds of chains (Fig. 2C). With fraction II, only one band (II-1) was obtained for the $\mathrm{B}$-chain of I-ricin $\mathrm{D}$ (lac); the fast-migrating



FIG. 1. Gel Filtration Patterns of Subtilisin Peptides Derived from the B-Chains of Ricin D Iodinated in the Absence (A) and Presence (B) of Lactose on a Sephadex G-25 Column $(1.9 \times 190 \mathrm{~cm}) \quad$ Using $0.5 \% \quad \mathrm{NH}_{4} \mathrm{HCO}_{3}$ Solution.

The solid line indicates peptides detected by absorbance at $230 \mathrm{~nm}$ and the dashed line indicates $\left[{ }^{125} \mathrm{I}\right]$ iodotyrosine containing peptides.

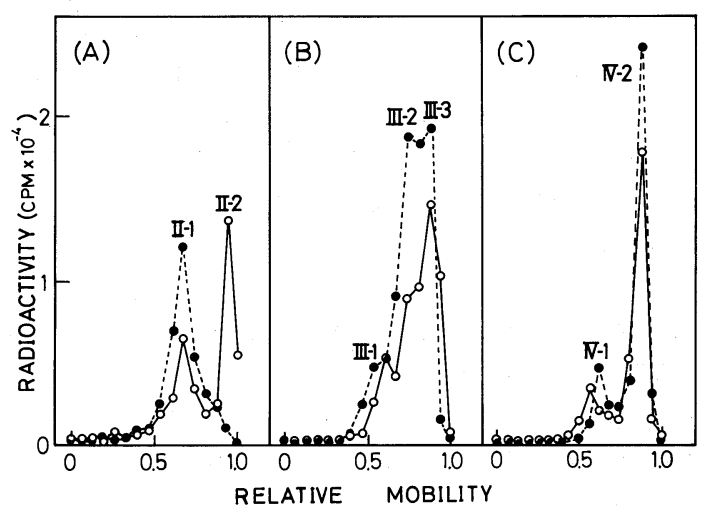

FIG. 2. Distribution of Radioactivity on Paper Chromatograms of Fractions II (A), III (B), and IV (C) Obtained in Fig. 1.

Fractions II, III, and IV derived from the B-chains of ricin $\mathrm{D}$ iodinated in the absence $(\mathrm{O})$ and presence $(O)$ of lactose were studied by decending paper chromatography. After development for $13 \mathrm{hr}$ using 1-BuOH-AcOH- $\mathrm{H}_{2} \mathrm{O}-$ pyridine $(15: 3: 12: 10)$, the paper was cut into $0.4 \mathrm{~cm}$ sections and the radioactivity counted. 
Table II. Amino Acid Compositions of $\left[{ }^{125}\right.$ I] Iodotyrosine Containing Peptides from the B-Chains of Ricin D Iodinated in the Presence and Absence of Lactose

$\left[{ }^{125} \mathrm{I}\right]$ Iodotyrosine containing peptides from the B-chains of ricin D iodinated in the presence and absence of lactose were purified by gel filtration on Sephadex G-25, paper chromatography, and paper electrophoresis. Peptides in the radioactive bands were extracted from the paper and thier amino acid composition was analyzed.

\begin{tabular}{|c|c|c|c|c|c|c|c|c|c|c|c|}
\hline \multirow[b]{3}{*}{$\begin{array}{c}\text { Bands } \\
\text { (Peptide) }\end{array}$} & \multicolumn{11}{|c|}{ Peptides from the B-chains of iodinated ricin D } \\
\hline & \multicolumn{6}{|c|}{ Without lactose } & \multicolumn{5}{|c|}{ With lactose } \\
\hline & $\begin{array}{c}\text { II-1 } \\
(\mathrm{S}-1)\end{array}$ & $\begin{array}{c}\text { II-2 } \\
(\mathrm{S}-5)\end{array}$ & $\begin{array}{l}\text { III-1 } \\
(\mathrm{S}-4)\end{array}$ & $\begin{array}{l}\text { III-2 } \\
(\mathrm{S}-1)\end{array}$ & $\begin{array}{l}\text { III-3 } \\
(\mathrm{S}-2)\end{array}$ & $\begin{array}{l}\text { IV-2 } \\
(\mathrm{S}-3)\end{array}$ & $\begin{array}{l}\text { II-1 } \\
(\mathrm{S}-1)\end{array}$ & $\begin{array}{l}\text { III-1 } \\
\text { (S-4) }\end{array}$ & $\begin{array}{l}\text { III-2 } \\
(\mathrm{S}-1)\end{array}$ & $\begin{array}{l}\text { III-3 } \\
(\mathrm{S}-2)\end{array}$ & $\begin{array}{l}\text { IV-2 } \\
(\mathrm{S}-3)\end{array}$ \\
\hline Thr (T) & 1.00 & & & 0.54 & & & 1.00 & & 0.92 & & \\
\hline Ser (S) & & & 0.99 & & & & & 0.76 & & & \\
\hline Pro (P) & & 1.06 & & & & & & & & & \\
\hline Gly (G) & 0.33 & 0.20 & 1.16 & 0.33 & & 1.04 & 0.66 & 1.07 & 0.34 & 0.36 & 1.09 \\
\hline Ala (A) & & & 0.85 & & & & & 0.82 & & & \\
\hline Ile (I) & & & & & 0.85 & & & & & 0.93 & \\
\hline Leu (L) & 0.32 & 1.94 & & & & 0.96 & 0.32 & & 0.50 & & 1.00 \\
\hline Tyr (Y) & 0.92 & 0.91 & 0.68 & 1.00 & 1.15 & 0.85 & 0.92 & 1.35 & 1.08 & 1.07 & 0.94 \\
\hline Yields $(\%)$ & 9.1 & 37.5 & 8.0 & 6.6 & 23.0 & 30.7 & 28.6 & 11.6 & 8.2 & 11.0 & 26.0 \\
\hline $\begin{array}{l}\text { Corresponding } \\
\text { sequence and }\end{array}$ & $\mathrm{T}-\mathrm{Y}$ & $\begin{array}{l}\text { L-Y- } \\
\text { P-L }\end{array}$ & $\begin{array}{l}\text { Y-A- } \\
\text { S-G }\end{array}$ & $\mathrm{T}-\mathrm{Y}$ & $\mathrm{I}-\mathrm{Y}$ & Y-G-L & $\mathrm{T}-\mathrm{Y}$ & $\begin{array}{l}\text { Y-A- } \\
\text { S-G }\end{array}$ & $\mathrm{T}-\mathrm{Y}$ & $\mathrm{I}-\mathrm{Y}$ & Y-G-L \\
\hline $\begin{array}{l}\text { position of } \\
\text { tyrosyl residue } \\
\text { in the B-chain }\end{array}$ & 67 & 248 & 176 & 67 & $\begin{array}{c}78 \text { or } \\
125\end{array}$ & 148 & 67 & 176 & 67 & $\begin{array}{c}78 \text { or } \\
125\end{array}$ & 148 \\
\hline
\end{tabular}

band (II-2) from the B-chain of I-ricin D was completely absent in that of I-ricin D(lac) (Fig. 2A). In fraction III, the radioactivity of the middle band (III-2) was lower than that of the fast-migrating band (III-3) in the B-chain of Iricin $\mathrm{D}$; these bands had about the same radioactivity in the chain from I-ricin $D(l a c)$ (Fig. 2B).

\section{Identification of peptides containing $\left[{ }^{125}\right.$ I]iodo-} tyrosyl residues

Peptides in the radioactive bands were extracted from the paper and their amino acid composition was analyzed. Since the bands, except for band II-2, contained several peptides, they were further purified by highvoltage paper electrophoresis at $\mathrm{pH} 1.8$. Amino acid compositions and the location in the primary structure of the purified peptides are shown in Table II. Band II-2 was pure peptide S-5 (residue 247 250) containing $\left[{ }^{125} \mathrm{I}\right] \mathrm{Tyr}-248$. From bands II-1 and III-2, pep- tide $\mathrm{S}-1$ (residue $66 \sim 67$ ) containing $\left[{ }^{125} \mathrm{I}\right] \mathrm{Tyr}$ 67 was isolated. The minor band III-1 gave peptide S-4 (residue 176 179) containing $\left[{ }^{125} \mathrm{I}\right] \mathrm{Tyr}-176$. Band III-3 gave peptide S-2 (IleTyr), which sequence was found at two different positions, residues $77 \sim 78$ and $124 \sim 125$. The iodinated tyrosyl residue present in peptide S-2, therefore, could be $\left[{ }^{125} \mathrm{I}\right] \mathrm{Tyr}-78,\left[{ }^{125} \mathrm{I}\right] \mathrm{Tyr}-125$, or both. No peptide was isolated from band IV-1. Peptide S-3 (residue $148 \sim 150$ ) containing $\left[{ }^{125} \mathrm{I}\right] \mathrm{Tyr}-148$ was isolated from band IV-2. The sequence of peptide S-3 was established based on the specificity of subtilisin BPN'.

\section{DISCUSSION}

In this experiment, subtilisin peptides containing $\left[{ }^{125} \mathrm{I}\right]$ iodotyrosyl residue were isolated from the B-chains of ricin D iodinated in the presence and absence of lactose, and the tyrosyl residue protected from iodination by 
lactose was identified. Since the isolated radioactive peptides except for a small amount of undigested material were of small molecular size, the reactivity of each tyrosyl residue in the B-chain toward iodination will also discussed on the basis of their yields.

The number of iodotyrosyl residues in the Bchain iodinated at $\mathrm{pH} 7.0$ and $0^{\circ} \mathrm{C}$ for $60 \mathrm{~min}$ using a 20 -fold molar excess iodine was about 3 , as reported before. ${ }^{5)}$ However, analysis of the subtilisin peptides containing $\left[{ }^{125}\right.$ I]iodotyrosyl residue from the iodinated B-chain showed that out of nine tyrosyl residues, 5 could be modified in the above condition. The remaining 4 residues, irrespective of the presence of lactose, are always inaccessible to the reagent; some of them may be buried inside the ricin $\mathrm{D}$ molecule. Yields of the peptides containing these 5 susceptible tyrosyl residues, varied from $8 \%$ to $38 \%$, suggesting that they have different susceptibilities to iodination; Tyr-248 seemed to be the most reactive, follower by Tyr-148 and Tyr-67; Tyr-176 was the least reactive. The reactivity of Tyr-78 and Tyr-125 was not clear, because it is possible that both tyrosyl residues are susceptible to iodination. The susceptibility of these less reactive residues to iodination may be partially hindered by neighboring groups.

Analysis of the peptides containing $\left[{ }^{125} \mathrm{I}\right]$ iodotyrosyl residue from the B-chain of ricin $\mathrm{D}$ iodinated in the presence of lactose showed that of these 5 susceptible tyrosyl residues, only Tyr-248 was completely protected from iodination. The tyrosyl residue protected from iodination by lactose is the one located in the HA-binding site of the B-chain, ${ }^{2)}$ so we concluded that the tyrosyl residue present in the HA-binding site of the B-chain is Tyr-248. However, we do not know if this tyrosyl residue is directly involved in or related to lactose binding, because the HA-binding site can bind to lactose even after the iodination of this tyrosyl residue. ${ }^{2}$

Concerning the susceptibility of the other 4 tyrosyl residues to iodination in the presence of lactose, the iodination of Tyr-148 and Tyr-176 was not much influenced by lactose, whereas that of Tyr-67 and Tyr-78 (or Tyr-125, or both) changed markedly; the reactivity of Tyr67 increased more than two-fold while that of Tyr-78 (or Tyr-125, or both) decreased by about half. This suggests that either a conformational alteration occurred in the B-chain by its binding to lactose or the iodination of Tyr78 (or Tyr-125, or both) was partially hindered by bound lactose, resulting in increased iodination of Tyr-67. Since the iodination of these tyrosyl residues was not completely prevented by lactose, and there was a loss of $60 \%$ of the cytoagglutinating activity of the B-chain, ${ }^{5)}$ they are not directly involved in lactose binding.

We reported elsewhere that the binding site inactivated by the iodination is the LA-, but not the HA-binding site, in which Tyr-248 is present. $^{2)}$ This result suggests that Tyr 67, Tyr-78, or both (or possibly Tyr-125) may be located near the LA-binding site and participate in its active conformation. If so, their iodination would cause the inactivation of the LA-binding site of the B-chain. Of course, the oxidation of tryptophan residues in the Bchain cannot be ruled out.

\section{REFERENCES}

1) M. Funatsu, G. Funatsu, M. Ishiguro, S. Nanno and K. Hara, Proc. Japan Acad., 47, 718 (1971).

2) T. Shimoda and G. Funatsu, Agric. Biol. Chem., 49, 2125 (1985).

3) G. L. Nicolson and J. Blaustein, Biochim. Biophys. Acta, 266, 536 (1972).

4) S. Olsnes and A. Pihl, "Receptors and Recognition," Series B, Vol. 1., ed. by P. Curtrecasas, Halsted, New York, 1976, p. 130.

5) T. Shimoda and G. Funatsu, Agric. Biol. Chem., 49, 1175 (1985).

6) K. Hara, M. Ishiguro, G. Funatsu and M. Funatsu, Agric. Biol. Chem., 38, 65 (1975).

7) M. Ishiguro, E. Taira, K. Mashima, G. Funatsu, M. Funatsu and M. Kikutani, Agric. Biol. Chem., 41, 299 (1977).

8) J. Roche, M. Michel and M. Lafou, Compt. Rend., 224, 233 (1947).

9) G. Funatsu, S. Miyauchi, M. Yoshizuka and M. Funatsu, Agric. Biol. Chem., 41, 1217 (1977).

10) T. Araki and G. Funatsu, FEBS Lett., 191, 121 (1985).

11) G. Funatsu, M. Kimura and M. Funatsu, Agric. Biol. Chem., 43, 2221 (1979). 